\title{
PENGARUH PROFITABILITAS, LIKUIDITAS, DAN ASSETS GROWTH TERHADAP KEBIJAKAN DIVIDEN PADA PERBANKAN YANG TERDAFTAR DI BURSA EFEK INDONESIA 2009-2018
}

\author{
Ricky Wijaya Setyadi \\ Program Studi Magister Manajemen Universitas Tarumanagara \\ rickywijayas@gmail.com \\ Yanuar \\ Program Studi Magister Manajemen Universitas Tarumanagara \\ Masuk : 02-12-2020, revisi : 20-12-2020, diterima untuk diterbitkan : 21-12-2020
}

\begin{abstract}
The purpose of this cognate is to inspect the influence of profitability, liquidity, and assets growth toward dividend policy on banking sector companies owned by the Indonesian government which is listed in the Indonesia Stock Exchange for ten years continuously from 2009 until 2018. The sample was determined by the purposeful distribution adjustment and the model is tested using the multiple linear regression method Eviews 11.00. The total sample ate 40 samples. Supported on the result the cognate it was establish that profitability and liqudity highly significant relationship on dividend policy, while growth show an insignificant relationship and have no impact on the dividend policy. This study provides input that investors in the capital market and company management should pay attention to the profitability and liquidity variables when investing in stocks, especially stocks in the banking sector because these variables have a significant effect on banking.
\end{abstract}

Keywords: Profitabilty, Liquidity, Assets Growth, Dividend Policy

Abstrak: Riset ini bertujuan buat mencari tahu pengaruh profitabilitas, likuiditas serta assets growth terhadap kebijakan dividen pada perusahaan perbankan milik pemerintah (BUMN) yang tercatat di Bursa Efek Indonesia selama 10 tahun berturut-turut dari tahun 2009 hingga tahun 2018. Tata cara pengambilan sampel adalah dengan menggunakan tata cara purposive sampling dan model diuji dengan tata cara regresi linier berganda dengan program Eviews 11.00. Jumlah sampel adalah sebanyak 40 sampel. Berdasarkan riset yang dilakukan, ditemui kalau profitabilitas dan likuiditas. memilikimpengaruh. signifikan terhadap kebijakan dividen., sedangkan assets growth tidak memiliki pengaruhmsignifikan terhadap kebijakan dividen. Studi ini memberikan masukan sebaiknya investor di pasar modal dan Managemen perusahaan, sebaiknya memperhatikan variabel Profitabilitas dan likuiditas ketika akan melakukan investasi pada saham khususnya pada saham sektor perbankan, karena variabel ini memiliki pengaruh yang signifikan terhadap perbankan.

Kata kunci: Profitabilitas, Likuiditas, Assets Growth, Kebijakan Dividen

\section{PENDAHULUAN}

Keputusan dividen ialah salah satu opsi susah yang wajib diambil oleh manajemen dalam mengalokasikan laba kepunyaan mereka buat diinvestasikan kembali dalam perusahaan atau di bagikan kepada para pemegang saham (Baker \& Powell, 2005, hal. 402). Meskipun telah banyak penelitian terhadap kebijakan dividen dilakukan tetapi praktik dividen perusahaan yang bervariasi dari waktu ke waktu, antar perusahaan dan lintas negara memberikan ketidakpastian dan perbedaan dari hasil tiap penelitian

Variabel profitabilitas terhadap kebijakan dividen pada riset yang diuji oleh Devandhen,dan Karthik (2015), mendapat bahwa profitabilitas memiliki pengaruh signifikan terhadap kebijakan dividen namun hasil riset ini bertentangan dengan riset Wahyudi (2018), 
variabel likuiditas terhadap kebijakan dividen pada riset yang diuji oleh Bostanci,et al (2018) menyatakan bahwa likuiditas memiliki pengaruh yang signifikan terhadap kebijakan dividen namun hasil riset ini bertentangan dengan riset yang diuji oleh Szymanska (2017), variabel growth assets terhadap kebijakan dividen pada riset yang di uji oleh Ahmad, dan Khan (2017) menyatakan bahwa growth assets memiliki pengaruh terhadap kebijakan dividen namun hasil riset ini bertentangan dengan riset yang diuji oleh Basri, H. (2019). Untuk menjawab literature gap ini, riset ini bertujuan untuk mencari tau pengaruh profitabilitas, likuiditas, dan growth assets terhadap kebijakan dividen pada perusahaan Perbankan BUMN yang ada di Indonesia. Research gap dalam riset ini di temukan pada variabel profitabilitas, likuiditas dan growth assets, sebab ada berbagai perbandingan hasil riset. Research gap ini menjadi celah untuk diteliti kembali dengan tujuan memperjelas penemuan - penemuan riset sebelumnya. Bersumber pada latar belakang tersebut maka peneliti tertarik melaksanakan penelitian terpaut variabel profitabilitas, likuiditas dan growth terhadap kebijakan dividen pada perusahaan perbankan milik pemerintah

Banyak faktor yang memperngaruhi kebijakan dividen yang dilakukan perusahaan. Pemilih memilih bank yang dimiliki pemerintah dikarenakan bank pemerintah (BUMN) menjadi salah satu bank yang selalu memberikan dividen. yang dimana diatur dalam Undangundang No. 40 tahun 2007 dan di pertegas di Peraturan Menteri Keuangan Republik Indonesia Nomor 5/PMK.02/2013 tentang tata cara penyetoran penerima negara bukan pajak dari dividen yang dimana perusahaan BUMN wajib membayarkan dividen. Sehingga riset ini bertujuan untuk mencari tahu variabel-variabel apa yang dapat mempengaruhi kebijakan dividen pada perusahan Perbankan milik BUMN. Berbagai penelitian yang telah dilakukan oleh para peneliti terdahulu memberikan hasil beragam dan ketidak konsistenan, dan masih sedikit penelitian yang di fokuskan di perusahaan perbankan milik BUMN. Oleh karena itu penelitan tertarik untuk melakukan penelitian kembali mengenai profitabilitas, likuiditas assets growth dan kebijakan dividen.

\section{TINJAUAN PUSTAKA}

\section{Hubungan Profitibilitas Dengan Kebijakan Dividen}

Menurut Abor dan Bokpin (2010), keputusan buat membayar dividen diawali dengan keuntungan oleh sebab itu logis untuk mempertimbangkan profitabilitas sebagai aspek yang dimana tingkat profitabilitas sebagai salah satu aspek terpenting yang bisa mempengaruhi keputusan dividen perusahaan. Hubungan profitabilitas dengan kebijakan dividen Rasio profitabilitas mengukur pendapatan atau keberhasilan operasi perusahaan dalam periode waktu tertentu (Weygandt et al., 2011) Perusahaan yang mendapatkan keuntungan umumnya hendak membayar bagian keuntungan yang lebih besar sebagai dividen. Semakin besar sebuah keuntungan yang dihasilkan oleh perusahaan maka akan semakin besar juga kemampuan perusahaan dalam membayar dividen.

\section{Hubungan Likuiditas Dengan Kebijakan Dividen}

Watson dan Head (2007), dalam studi mereka menyimpulkan bahwa perusahaan sebelum membayar dividen harus memperhatikan likuiditasnya meskipun tinggi keuntungan. Mereka berargumen bahwa keuntungan tidak sama dengan uang tunai dan oleh karena itu jumlah dividen yang dibayarkan harus mempresentasikan bukan cuma keuntungan perusahaan tetapi kemampuannya buat membayar dividen. Semakin tinggi tingkat likuiditas, maka akan semakin tinggi juga kemampuan perusahaan untuk membayar dividen kepada para pemegang saham (Yohannes dan Venkati 2016).

\section{Hubungan Assets Growth Dengan Kebijakan Dividen}

Menurut Setiawan dan Phua (2013) Perusahaan dengan perkembangan yang lebih tinggi lebih suka melakukan investasikan kembali terhadap pendapatan mereka untuk pertumbuhan perusahaan mereka daripada mengalokasikannya ke para pemegang saham. Semakin tinggi tingkat perkembangan suatu perusahaan, semakin tinggi kebutuhan dana perusahaan 
menginvestasikan kembali. Menurut Wahjudi (2018) menyatakan bahwa perkembangan total aset akan menurunkan pembayaran dividen kepada para pemegang saham karena manajer perusahaan memanfaatkan keuntungan perusahaan untuk aktivitas pendanaan internal membuka peluang investasi, sehingga pertumbuhan total aset semakin besarakan menghasilkan pembayaran dividen yang lebih rendah.

Berdasarkan hubungan antar variabel diatas maka dapat diambil hipotesis yaitu:

H1 : Terdapat.pengaruh signifikan antara profitabilitas dengan kebijakan dividen

$\mathrm{H} 2$ : Terdapat.pengaruh signifikan antara likuiditas dengan kebijakan dividen

H3 : Terdapat.pengaruh signifikan antara Assets Growth dengan kebijakan dividen

\section{Gambar 1}

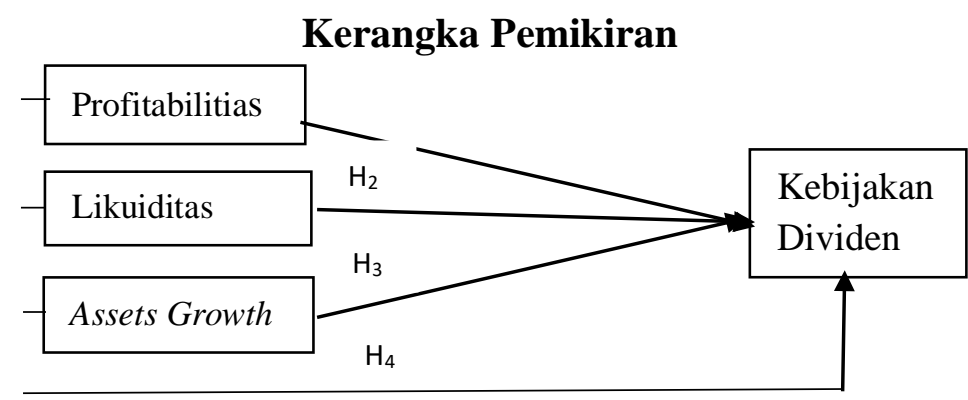

\section{METODOLOGI PENELITIAN \\ Metode analisis}

Regresi panel merupakan tata cara analisis informasi data yang bisa digunakan dalam riset ini sebab riset dilakukan untuk mencari tahu hubungan ikatan keterkaitan antara variabel independen dengan variabel dependen pada data longitudinal (Winarno,2017). Aplikasi Program yang dipakai buat menguji data penelitian ini yaitu aplikasi program Eviews 11.0. Tahap- tahapan analisis informasi data meliputi statistik deskriptif, uji outlier, pemilihan model terbaik dengan uji Chow serta uji Hausman, uji F, uji t, dan juga uji Koefisien Determinasi (R2).

\section{Populasi dan Sampel}

Populasi dalam riset ini berupa perusahaan perbankan milik BUMN yang tercatat di Bursa Efek Indonesia Periode 2009-2018. Teknik pemilihan sampel dilakukan dengan menggunakan purposive sampling dimana kriteria pemilihan sampel yang pertama adalah Perusahaan perbankan milik pemerintah yang menerbitkan laporan keuangan yang diaudit antara tahun 2009-2018. Kedua Perusahaan perbankan milik pemerintah yang menerbitkan laporan keuangan yang diaudit antara tahun 2009-2018. Berdasarkan barometer tersebut jumlah perusahaan yang memenuhi kriteria sebagai sampel berjumlah 4 yaitu PT Bank Mandiri (Persero) Tbk, PT Bank Negara Indonesia (Persero)Tbk, PT Bank Rakyat Indonesia (Persero) Tbk, dan PT Bank Tabungan Negara (Persero) Tbk.

\section{Operasional Variabel \& Pengukuran}

Operasionalisasi variabel dan pengukuran dalam penelitian ini terbagi menjadi dua yaitu variabel bebas (variabel independen), dan variabel terikat (variabel dependen) yaitu:

\section{Kebijakan dividen}

Dalam penelitian proksi pengukuran kebijakan dividen menggunkan dividen payout ratio. Kebijakan dividen penelitian ini diukur dengan rumus sebagai berikut:

\section{Profitabilitas}

$$
\text { Dividen Pay Ratio }=\frac{\text { Dividen Per Share }}{\text { Earning Per Share }} \times 100 \% \quad \text { : Persamaan } 1
$$

Dalam penelitian proksi pengukuran profitabilitas menggunakan Return on Assets (ROA). Profitabilitas penelitian ini diukur dengan rumus sebagai berikut :

$$
R O A=\frac{\text { Earning After tax }(E A T)}{\text { Total Asset }} \times 100 \% \quad \text { : Persamaan } 2
$$




\section{Likuiditas}

Dalam penelitiann ini proksi pengukuran likuiditas menggunakan Loan to Deposit Ratio (LDR). likuiditas penelitian ini diukur dengan rumus sebagai berikut :

4. Assets Growth

$$
\text { Loan to Deposit Ratio }=\frac{\text { Total Loan }}{\text { Total Deposit }+ \text { Equity }} \times 100 \% \quad \text { : Persamaan } 3
$$

5. Dalam penelitian proksi assets growth diukur mengunakan asset growth. assets growth penelitian ini diukur dengan rumus sebagai berikut :

$$
\text { Asset Growth }=\frac{\text { Total Asset }(t)-\text { Total Asset }(t-1)}{\text { Total Asset }(t-1)} \times 100 \% \quad \text { : Persamaan } 4
$$

\section{HASIL PENELITAN}

Hasil Uji untuk melihat hasil hubungan antara variabel profitabilitas, likuiditas, dan asset growth terhadap kebijakan dividen dapat dilihat pada tabel 1

\section{Tabel 1}

\begin{tabular}{|c|c|c|c|c|}
\hline Variable & Coefficient & Std. Error & t-Statistic & Prob. \\
\hline DPR & 0.077718 & 0.134610 & 0.577359 & 0.5676 \\
\hline ROA & -4.671293 & 1.957883 & -2.385890 & 0.0229 \\
\hline LDR & 0.465042 & 0.133440 & 3.485038 & 0.0014 \\
\hline AG & -0.312288 & 0.178022 & -1.754216 & 0.0887 \\
\hline \multicolumn{5}{|c|}{ Effects Specification } \\
\hline \multicolumn{5}{|c|}{ Cross-section fixed (dummy variables) } \\
\hline Root MSE & 0.055504 & \multicolumn{2}{|l|}{ R-squared } & 0.568463 \\
\hline Mean dependent var & 0.286000 & \multicolumn{2}{|c|}{ Adjusted R-squared } & 0.490001 \\
\hline S.D. dependent var & 0.085569 & \multicolumn{2}{|c|}{ S.E. of regression } & 0.061108 \\
\hline Akaike info criterion & -2.594707 & \multicolumn{2}{|c|}{ Sum squared resid } & 0.123230 \\
\hline Schwarz criterion & -2.299153 & \multicolumn{2}{|c|}{ Log likelihood } & 58.89414 \\
\hline Hannan-Quinn criter & -2.487844 & \multicolumn{2}{|c|}{ F-statistic } & 7.245135 \\
\hline Durbin-Watson stat & 1.716264 & \multicolumn{2}{|c|}{ Prob(F-statistic) } & 0.000054 \\
\hline
\end{tabular}

\section{Output pengelolahan data panel}

Data diolah $: 2020$

Pada penelitian ini telah dilakukan uji Chow dan uji Housman yang dimana di peroleh kesimpulan model penelitian yang digunakan menggunakan model fixed effects

Hasil Analisis Regresi Berganda pada riset ini, dapat disimpulkan persamaan 5 model regresi yaitu:

$\mathrm{DPR}=\mathbf{0 , 0 7 7 7 1 8}+(-\mathbf{- 4 , 6 7 1 2 9 3}) \mathrm{ROA}+\mathbf{0 , 4 6 5 0 4 2} \mathrm{LDR}+\mathbf{( - 0 , 3 1 2 2 8 8}) \mathrm{AG}+\boldsymbol{\varepsilon} \quad:$ Persamaan 5 Interpretasi terhadap persamaan 5 dapat dijelaskan sebagai berikut :

1. apabila seluruh variabel independen diabaikan atau senantiasa, hingga nilai variabel kebijakan dividen cuma sebesar konstantanya saja, ialah sebesar 0,077718

2. koefisien regresi $\beta 1$ ini menampilkan kalau setiap variabel profitabilitas (ROA) mempunyai koefisien regresi bertanda negatif dengan nilai sebesar -4,671293 yang berarti apabila ada perubahan pada variabel profitabilitas (ROA) sebesar satu satuan, maka akan mengakibatkan penurunan kebijakan dividen sebesar -4,671293 dengan anggapan variabel independen yang lain dianggap tetap

3. koefisien regresi $\beta 2$ ini menampilkan kalau setiap variabel likuiditas (LDR) mempunyai koefisien regresi bertanda positif dengan nilai sebesar 0,465042 yang berarti apabila ada perubahan pada variabel likuiditas (LDR) sebesar satu satuan, maka akan mengakibatkan peningkatan Kebijakan dividen besar 0,465042 dengan anggapan variabel independen lainnya dianggap tetap

4. koefisien regresi $\beta 2$ ini menampilakn kalau setiap variabel assets growth (AG) mempunyai koefisien regresi bertanda negatif dengan nilai sebesar -0,312288 yang berarti apabila terdapat perubahan pada variabel assets growth (AG) sebesar satu satuan, 
maka akan mengakibatkan penurunan kebijakan dividen besar -0,312288 dengan anggapan variabel independen lainnya dianggap tetap

Hasil Uji Hipotesis dengan Uji-t (Coefficients) menunjukkan bahwa:

1. variabel profitabilitas (ROA) menunjukan nilai prob sebesar 0,0229 (lebih kecil dari $\alpha=$ 0,05), sehingga profitabilitas (ROA) berpengaruh signifikan terhadap Kebijakan dividen,

2. variabel likuiditas (LDR) menunjukkan nilai prob sebesar 0,0014 (lebih kecil dari $\alpha=$ 0,05), sehingga likuiditas (LDR) berpengaruh signifikan terhadap kebijakan dividen,

3. variabel assets growth (AG) menunjukkan nilai prob sebesar 0,0887 (lebih besar dari $\alpha$ $=0,05)$, sehingga assets growth (AG) tidak berpengaruh signifikan terhadap kebijakan dividen, tetapi signifikan pada pada $\alpha 10 \%$

Nilai Adjusted R2 pada tabel.1 adalah sebesar 0,490001 artinya besarnya variasi dari variabel Kebijakan dividen (variabel dependen) yang dapat dijelaskan oleh variabel profitabilitas (ROA), likuiditas (LDR) dan assets growth (AG) (variabel independen) adalah sebesar 49,0001\% dan sisanya 50,9999\% dijelaskan oleh variabel-variabel lain yang tidak dijelaskan dalam model regresi ini.

\section{KESIMPULAN}

Berdasarkan hasil pengolahan data yang telah dilakukan maka dapat ditarik kesimpulan dalam penelitian ini yaitu :

1. Profitabilitas (ROA) berpengaruh terhadap kebijakan dividen (DPR) untuk sepuluh tahun pengamatan (2009-2018). Hasil riset ini sejalan dengan hasil Amidu dan Abor (2006), Zhong (2016) dan Singla dan Samanta (2018) yang dimana profitabilitas mempunyai pengaruh yang signifikan terhadap kebijakan dividen.

2. Likuiditas (LDR) berpengaruh terhadap kebijakan dividen (DPR) untuk sepuluh tahun pengamatan (2009-2018). Hasil riset ini sejalan dengan hasil Yohannes dan Venkati (2016), Ahmad dan Khan (2017), dan Bostanci et al (2018) yang mengemukakan bahwa likuiditas berpengaruh positif signifikan terhadap kebijakan dividen.

3. Asset growth (AG) berpengaruh terhadap kebijakan dividen (DPR) untuk sepuluh tahun pengamatan (2009-2018). Hasil ini sejalan dengan hasil Devandhen dan Karthik (2015), dan Bashri (2017) dimana asset growth tidak memberikan pengaruh yang signifikan terhadap kebijakan dividen.

\section{IMPLIKASI}

Berdasarkan hasil penelitian diatas dimana dimana profitabilitas dan likuiditas memiliki pengaruh yang signifikan terhadap kebijakan dividen sebaiknya Bagi investor di pasar modal dan Managemen perusahaan , sebaiknya lebih memperhatikan variabel Profitabilitas dan likuiditas ketika akan melakukan investasi pada saham khususnya pada saham sektor perbankan, karena variabel ini memiliki pengaruh yang signifikan terhadap perbankan.

\section{DAFTAR PUSAKA}

Baker, H. K., \& Powell, G. (2005). Understanding Financial Management: A Practical Guide. Blackwell Publishing, Oxford

Baker, H. K., Singleton, C., \& Veit, E. T. (2009). Survey Research in Corporate Finance: Bridging Thr Gap between Theory and Practice. New York: Oxford University Press.

Basri, H. (2019). Assessing determinants of dividend policy of the government-owned companies in Indonesia. International Journal of Law and Management, 61(5/6), 530541.

Black, F. (1976). The Dividend Puzzle. Journal of Portfolio Management.

Bostanci, F., Kadioglu, E., \& Sayilgan, G. (2018). Determinants of dividend payout decisions: A dynamic panel data analysis of Turkish stock market. International Journal of Financial Studies. 
Bringham, \& Ehrhardt. (2008). Financial Management: Theory and Practice. 12th Edition. Thomson South-Western-Ohio: United State of America.

Devanadhen, K. \& Karthik, P. (2015). Determinants of dividend policy of public and private commercial bank in india: a panel data approach. International Refereed Reseacrh Journal, 6(3).

Khan A. F., \& Ahmad, N. (2017). Determinats of dividend payout: An empirical study of phamaceutical companies of Pakistan stock exchange (PSX). Journal of Financial Studies \& Research.

Jensen, M. C., \& Meckling, W. H. (1976). Theory of the firm: Managerial behavior, agency cost and ownership structure. Journal of Financial Economics, 3.

Setiawan, \& Phua. (2013). Corporate governance and dividend policy in Indonesia. Journal Business Strategy Series, 14(5/6).

Szymańska, A. G. (2017). Impact Of a company's dividend policy on the liquidity of shares listed on the Warsaw stock exchange. Financial Internet Quarterly e-Finanse, 13(3), 2432

Wahjudi, E. (2018). Factors affecting dividend policy in manufacturing companies in Indonesia Stock Exchange. Journal of Management Development, 39(1), 4-17.

Waston, D., \& Head A. (2019). Corporate Finance: principles \& practice 8th Edition

Winarno, W. W. (2012). Analisis Ekonometrika dan Statistika dengan Eviews Edisi 4. Yogyakarta: UPP STIM YKPN

Weygandt, J. J., Paul, D. K. \& Donald, E. K. (2011), Financial Accounting, IFRS Edition. John Wiley and Sons, Amerika, NJ. 